\title{
СПЕКТРОФОТОМЕТРИЧЕСКОЕ ОПРЕДЕЛЕНИЕ ЦЕФУРОКСИМА И ЦЕФОПЕРАЗОНА В СОЕДИНЕНИЯХ С МЕТАЛЛАМИ
}

Новикова Г.В., Демина А.В.

Сибирский федеральный университет, Красноярск, Россия

galina-n@mail.ru

DOI: 10.26902/ASFE-11_177

Цефуроксим и цефоперазон - цефалоспориновые антибиотики II и III поколения, хорошо зарекомендовали себя в лечении против грамотрицательных и грамположительных бактерий (Рис.1). Бактерицидное действие антибиотиков связано с подавлением синтеза клеточной стенки бактерий.

На фармацевтических предприятиях цефуроксим и цефоперазон определяют с помощью ВЭЖХ согласно ГОСТу, с последующим пересчетом на форму кислоты. Присутствие в соединении ионов металлов не позволяет использовать данный метод количественного определения антибиотиков. Альтернативным способом определения является элементный анализ на углерод, водород, серу и азот, однако данный метод не показывает, происходит ли частичное разрушение антибиотика.

Предложена методика спектрофотометрического определения цефуроксима и цефоперазона в растворе. Исследуемые препараты (натриевые соли антибиотиков) растворяли в фосфатном буфере с $\mathrm{pH}=6,5$. Измерение оптической плотности (А) растворов проводили в диапазоне длин волн 220-450 нм, использовали кварцевые кюветы с толщиной поглощающего слоя (l) 1 см, в качестве раствора сравнения - фосфатный буфер. При построении градуировочного графика готовили растворы антибиотиков с концентрациями в интервале от $1 \cdot 10^{-5}-1 \cdot 10^{-4}$ моль/л. На рисунке 2 приведены электронные спектры поглощения антибиотиков. Использовали оптические плотности растворов при длинах волн равных 228, 263 нм для цефоперазона и 275 нм для цефуроксима, что соответствовало пикам максимума поглощения. Из градуировочных графиков были определены значения молярных коэффициентов экстинкции ( $\varepsilon$ д для цефоперазона: 20942 л/(моль•см) при 228 нм, 13887 л/(моль•см) при 263 нм; для цефуроксима: 7831 л/(моль·см) при 275 нм. При определении содержания антибиотиков в соединениях с металлами, ионы металлов предварительно удалялись из раствора.
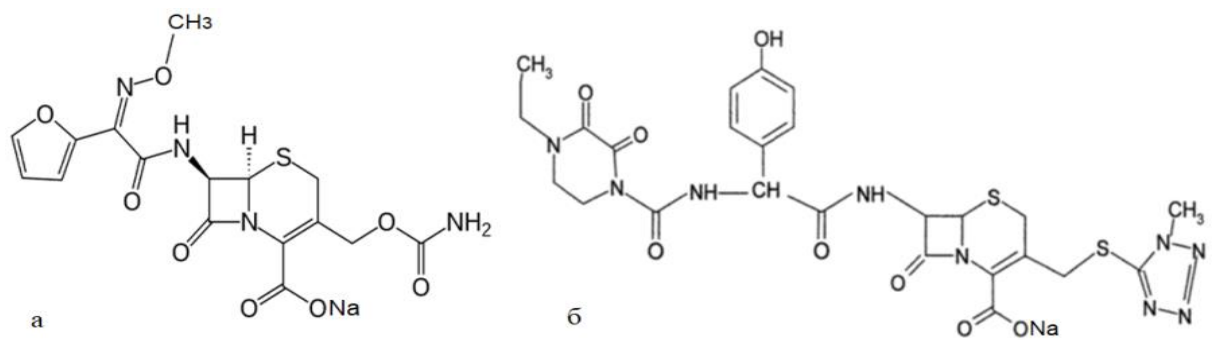

Рис. 1 Графическая формула цефуроксима (а) и цефоперазона (б)

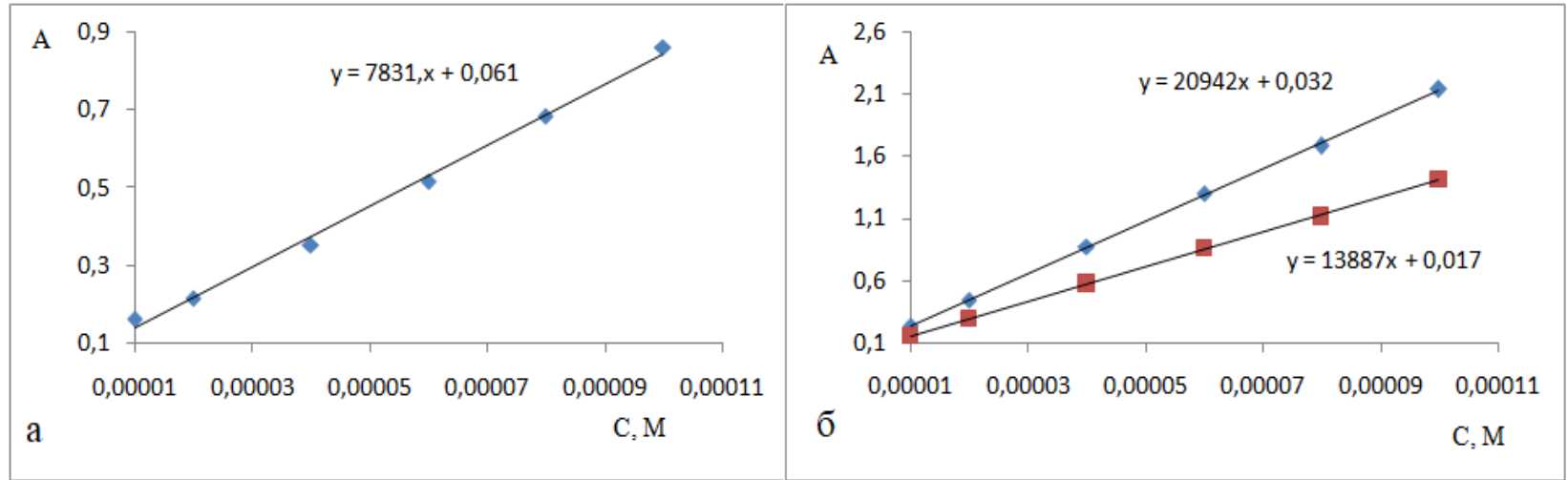

Рис. 2 Градуировочные графики для определения цефуроксима (а) и цефоперазона (б) 